\title{
Aeromonas punctata
}

National Cancer Institute

\section{Source}

National Cancer Institute. Aeromonas punctata. NCI Thesaurus. Code C86127.

A species of Gram negative, rod shaped bacteria assigned to the phylum Proteobacteria.

This bacteria is motile, oxidase and catalase positive, beta hemolytic and produces gas

from glucose. A. punctata is commonly found in soil and water and can cause dropsy in fish. 